\title{
Baianas de Acarajé against FIFA: Coloniality Nowadays ${ }^{2}$
}

Women from many generations work as baianas de acarajé, a popular knowledge that has been passed down for many centuries in (mainly) the state of Bahia, Brazil. Baiana de acarajé is an afro-Brazilian craft, performed by autonomous women who work as street vendors of food, such as acarajé, abará, "student cake", cocada, among others. During the period of slavery (1500-1888), the trade of acarajé helped many enslaved women to buy their freedom (Torres 2007). Indeed, during and after the colonial period (1500-1822), this craft meant the only alternative of supporting their communities and guaranteeing their economy, culture and religion (IPHAN 2007). Until nowadays, whole families are sustained with the trade of acarajé and other food products (personal communications, 2013).

Since 1992, baianas de acarajé have been united in an association that represents their interest as street vendors. Since its creation, the Associação de Baianas de Acarajé e Mingau (Association of Baianas de Acarajé and Mingau - ABAM) has won the right to work as autonomous workers in the city of Salvador, in the state of Bahia. Indeed, due to disputes with evangelic baianas who sell acarajé as "jesus cake" and with enterprises that were selling pre-cooked and freezed acarajé, ABAM

\footnotetext{
${ }^{1}$ LaRISSA DA Silva ARAujo is a PhD student at the Graduate Institute of Development Studies (IHEID) in Geneva, Switzerland.

${ }^{2}$ This article was originally published in http://www.alternautas.net/blog/2020/4/2/baianas-deacaraj-against-fifa-coloniality-nowadays
} 
worked in collaboration with the Instituto Nacional de Patrimônio Histórico e Cultural (National Institute of Historical and Cultural Heritage - IPHAN) to include the craft of baianas de acarajé in the Book of Knowledges. Hence, since 2007, IPHAN has defined what are the characteristics of their craft (how they should dress, the cooking procedures and its cultural and religious meaning) and recognized their craft as a national intangible heritage. This title helped them to overcome these disputes with evangelic groups and private companies.

The dispute with FIFA started in 2012, when baianas de acarajé discovered they would not be allowed to practice their craft during the FIFA World Cup 2014. At that moment, it was FIFA who decided who could work in its "exclusive zones". Once baianas de acaraje had not participated on FIFA's binding process, they were excluded from these exclusive zones. Since then, baianas started to act to guarantee their right to work, mobilizing the language of the state and the language of the streets to achieve this goal.

According to their narratives, baianas de acarajé started selling acarajé inside football stadiums at least 50 years ago. But during preparatory works for megaevents held in Brazil in 2014 and 2016, numerous human rights violations happened throughout the construction works in order to comply with the requirements of international capital. In this essay, departing from baianas de acarajé narratives, I interpret in which way hosting the 2014 Fédération Internationale de Football Association (International Federation of Football Associations - FIFA) World Cup interfered on their lives and how they reacted to it.

I draw on the narratives of baianas de acarajé, expressed through conversations and semi-structured interviews conducted during ethnographic fieldwork, as well as, on laws and materials related to the case were analyzed - namely, the Lei Geral da Copa (General Cup Law), the Duties Matrix of World Cup and its additaments (governmental budgets to works and other projects related to World Cup, such as stadiums, airports, etc), the recommendation of Public Prosecution that defended baianas de acarajé, FIFA's bidding documents, FIFA's and touristic public enterprises ads, the online petition organized by the Association of Baianas de Acarajé (ABAM) and a systematization document of an evaluation meeting 
produced by baianas de acarajé. I also used media sources, like interviews, statements and news. With these sources, I could identify this narrative of the facts, as well as comprehend the official discourses that were constructed and mobilized to justify the realization of mega events.

Analyzing the case through intersectionality and the perspective of situated knowledge, I am able to focus on more than one category of analysis (gender, race and coloniality). Thus, I consider the categories are articulated on the same structure of domination and exploitation that constitutes and supports the power relations between the subjects through their interaction. Indeed, these perspectives allowed me to investigate the case study through baianas de acarajés lens. They had the privilege of knowing the whole with more details, even though they occupied an unprivileged position on this dispute (Haraway 1995 apud Cardoso 2012).

\section{Baianas de acarajé excluded by FIFA}

On October 2012, ABAM's president discovered that they would not have permission to sell on the "exclusive FIFA zones" from a journalist of a local newspaper. They had not participated on FIFA's bidding process of trading concession for food and beverage companies ${ }^{3}$, a process opened in January of that year. In Salvador (capital of Bahia state), exclusive FIFA zones constituted places either inside of or contiguous to neighborhoods of the stadium Fonte Nova Arena and of "FIFA Fan Fests". In these exclusive FIFA zones, only FIFA, its sponsors and licensed companies would be permitted to trade, so FIFA could guarantee its profits from the mega event.

On May 29th, 2013, FIFA announced the bidding process result. The concessionaires Aramark and Convivas Brasil were selected to sell the products of enterprises sponsoring the mega event. Aramark is a USA company with an annual

\footnotetext{
${ }^{3}$ Invitation to tender for the rights of the FIFA Food \& Beverage Concessionaire Programme Phase I (Fifa 2012).
} 
profit of 15 billion US dollars, which sells food and clothes across 22 countries. Convivas Brasil is a subsidiary in Brazil of a Swiss transnational company, responsible for a platform of service providers in corporate hospitality and event management. In their press statement, FIFA also announced that on the menu of foods offered by the companies would have options of typical regional dishes, such as acarajé in Salvador, feijão tropeiro in Belo Horizonte and the bolo de rolo in Recife and that the companies would work with local Brazilian service providers.

In my first visit to Salvador, in September 2013, I talked for the first time with baianas de acarajé directly involved with the dispute during a meeting of Popular Committees for World Cup (ANCOP). They told me they were afraid of being excluded from the World Cup. It meant they would probably be incorporated by other companies or lose their "selling points", consequently losing their autonomy and management of production, resulting in a collective loss of traditional aspects of their work. Even though the production of acarajé has been resignified and modified through the years, some aspects remain during the twentieth and twentyfirst centuries: the presence of baianas on the public space, the detention of ritualistic and culinary knowledge, passed through the generations, and the autonomy on the production and trade process (Torres 2007; Brasil 2007; Souza 2012; Santos 2013).

They were worried with the lack of options to maintain their income during the games and the importance of their presence in the public space. It was clear to them that the exceptional situation, temporarily installed with World Cup, could quickly become permanent.

Additionally, acarajé is not only a different food, produced with "exotic" ingredients and typical of Afro-Brazilian cuisine. This food is inserted in a food system that involves different subjects and knowledges, from its production to its consumption. There is an extensive literature on the anthropology of food that deals with the meanings that food can have. According to Lima (2010: 40 in Santos 2013), food can be taken in a comprehensive sense, as a system that goes from the consumption and involves the forms of social interaction, symbolic expression and ritualization. Machado explains that the messmate, when eating, "shares a system of 
definitions of what is 'edible' and 'tasty', incorporating properly the definitions of a food system that makes it part of a group" (2013: 241, my translation).

Indeed, the knowledge that involves the production of acarajé is called craft precisely because there is a secrecy around it, known only by the members of this food system and by the practitioners of an afro-Brazilian religion called candomblé. In this religion, acarajé is a votive food, that is, it is a food offered to Iansã/Oiá, a warrior orixá (goddess) that is the protector of this food and of those who cook it. According to the legend, Iansa taught other women how to cook this food and they must keep the tradition, teaching the secrecy to other female relatives (Iphan 2007; Torres 2007). That's the reason the majority of baianas de acarajé are women, and in general the knowledge about the craft is passed from mothers to daughters or other young women from their kinship networks. In general, even baianas who are guided by other orixás or are believers of other religions respect the origins of the craft in candomblé, acknowledging the importance of Iansã as protector of the craft (Santos, 2013). Out of this context, offered to the public by foreign companies, the food would stop integrating this alimentary system and would come to have simply a material value, of commodity.

Finally, baianas de acarajé are self-employed autonomous traders. Thus, the prospect of work as employees of multinational companies, selling the acarajé as a mere commodity - withdrawing it from the food system of which it is part and revealing the secrecy of their craft - was not an attractive one for them.

Until the inauguration of the Fonte Nova Arena in April 2013, two months before the FIFA Confederations Cup, considered the test for the World Cup, the entity had not yet decided whether baianas would be granted permission to carry out their trade in exclusive FIFA zones.

\section{Baianas de acarajé acting against FIFA prohibition - heritage and direct action}

Known for loving football, a significant part of the Brazilian population was excited about Brazil hosting the World Cup, not only because it would incentive national development, but because they would be able to watch the biggest football party in 
person. Thinking on their symbolic importance for national culture, since baianas de acarajé represent not only afro-Brazilian traditions but Brazilian population, they assumed FIFA and Brazilian government would not exclude them from this important event and this trouble could be overcome. When they learned of the bidding, which they could not join, and of FIFA's ban, the baianas began to think about and articulate strategies to negotiate with the public power.

First, Baianas de Acarajé Association tried to negotiate with Brazilian government, in its different spheres and public bodies, with institutions from local, provincial and national government, their standing and trading during 2014 FIFA World Cup, without FIFA's restrictions. However, they considered to move to another strategy when Brazilian government assumed that "the owner of the party is the one who pays for it" (as said the Ministry of Culture to ABAM). In this case, supposedly FIFA was paying for it, so the entity had the power to determine whether baianas de acarajé could work or not during the World Cup. After negotiations, baianas de acarajé decided use tactics of direct action, through virtual mobilization and protests in front of the new stadium. With these strategies, they gained national and international attention to their problem and were heard by the government and FIFA.

With the support from the international NGO Change.org organizing online petitions, ABAM carried out a campaign to collect signatures in support of their stay in exclusive zones. The petition was addressed to the national representative of the Local Organizing Committee, composed of former Football Player Ronaldo Nazareno, FIFA's President Joseph Blatter, Sports Minister Aldo Rebelo, SECOPA Secretary Ney Campello and the Head of SECOPA's office, Lilian Pitanga. The online petition lasted for eight months and collected more than 17,000 signatures.

On April 5, 2013, the day of the inauguration of Fonte Nova Arena, baianas protested on Avenida Dique, in front of the stadium. They distributed t-shirts from the state's most well-known soccer teams, Bahia and Vitória, as well as acarajés to passers-by and to the drivers of vehicles. The objective was to draw the attention of the public authorities that arrived for the inauguration of the stadium. The Presidency of the Republic's advisor, José Claudionor, received the petition 
requesting the permanent return of baianas to the stadium, not only during the mega-events.

According to baianas, although they always participated in events representing Afro-Bahian tradition and culture, they had not been invited to the inauguration. So, they wanted to manifest their indignation in front of the new stadium. In addition, they also made a strong complaint against the consortium that rebuilt the Arena (Fonte Nova Negócios e Participaçóes SA), since it did not envision and construct commercial spaces for them inside the building.

Even though some state organs received a recommendation of the Public Prosecution Office for acting in favor of baianas de acarajé, they remained inactive. In the sequence, the Public Prosecution Office filed an injunction to guarantee to the entry of baianas during the Confederations Cup. From then on, they got support from the Federal Government, which intervened and asked FIFA to make an exception for them. According to ABAM president, about a month before the Confederations Cup, FIFA had authorized six baianas to sell acarajé at the Fonte Nova Arena. However, the authorization was not yet definitive, as it would be a "test" for the 2014 World Cup.

On October 26, 2012, the governor of the State of Bahia, Jacques Vagner, gave baianas the title of State Intangible Heritage. This title, like the one granted by the Institute of National Historical and Artistic Patrimony (IPHAN) in 2007, emphasized the importance of the craft of baianas de acarajé as a state heritage, recognizing their work as a craft that must be preserved and perpetuated through the support of public policies.

At the ceremony of delivery of the title, the governor granted an interview saying that it was inconceivable not to have baianas de acarajé inside the Arena Fonte Nova. However, according to president of ABAM, whenever the baianas sought state support, they were not answered. In this case, IPHAN was silent and did not contribute to the protection of the baianas' craft.

In all narratives, in various situations, during informal conversations, interviews, before and after the World Cup, baianas emphasized their desire to be respected. 
The expressions "we want respect", "we want to be respected", "our work deserves respect", "I want to be treated with respect and dignity", "without respect and no dignity ... we do not support", appeared constantly, often tied to the evaluation of "having heritage", as "they gave us the title of heritage, then you have to respect us", "we thought that when we became a cultural heritage, the state would embrace us and protect us as if we were daughters, but we are disrespected nonetheless", "I would like them to respect us more and make the IPHAN document valid, because baianas are a national intangible heritage" (personal communications, 2014).

The feeling of indignation and revolt expressed by these women was driven by the lack of respect that resulted from the established power relations. Their narratives also provoked me to reflect on the role that recognition through the title of heritage exercises in this dispute between baianas, FIFA and the State. Baianas expected respect for their condition - as a black woman, an autonomous worker, households, member of Afro-descendant communities, inheritors of a specific knowledge would finally happen. Moreover, I could also perceive the expectation that the heritage title would raise them to a level of greater interlocution with the State and with FIFA, open channels of dialogue with the institutions and allow them to conquer public policies of protection, safeguarding their craft and fostering the autonomous initiative of other women.

In the dispute with FIFA the title of heritage also helped them to claim their rights. However, they consider the title has also trapped them in a static conception of the traditional and the cultural. In the case of the expectation of greater dialogue with the State and FIFA, baianas considered that the use of the heritage instrument was an important strategy. According to one baiana, "we put the title of heritage in front of the dispute", arguing it was the State's obligation to safeguard the knowledge protected as heritage. Through this argument, they managed to acquire the authorization for working in the zones of exclusion. Both in the online petition and in the recommendation of the Public Prosecutor to the state secretariats, the title of heritage was mobilized as a key concept.

On the one hand, the title of heritage implies the recognition of the uniqueness of the identity of baianas de acarajé, a political identity that distinguishes the craft of 
these women as a knowledge of their own. In their narratives, there is pride in this recognition.

On the other hand, when speaking about this subject, they also questioned me about the usefulness of this title, because it brings them obligations (wearing typical clothes every day, for example) without concrete counterparts of safeguard and protection. Accordingly, the tourism-related institutions of Bahia and Salvador view them as postcards, exhibiting them as exotic representatives of African traditions in the country. However, there are no policies that integrate baianas with tourism actions. Even when they got permission to enter the stadium, there was no support for them, such as a specific line of credit for the World Cup or subsidy for the proper installation of their trays. Thus, in their narratives, there is also a claim that until now heritage has not been useful, making no difference in their lives or only serve to companies from the tourism sector to use it as a justification to exploit them.

In this sense, the title of the heritage acquired an ambiguous character: baianas understand its importance as a method of translation of their yearnings and demands to the language of Law, necessary to challenge the State. However, it has also become a right with empty material content, since the actions in the public policy level, necessary to give shape to this right, are not realized. In fact, it creates for them an obligation to maintain themselves in the form that the heritage conceived them. In short, they are recognized as subject to the law, but are not recognized as agents of this right. Thus, it is evident that the State dialogues with the "Other" through the code that it created to classify and dialogue with this Other.

\section{Baianas' perspective of resistance - amefricanidade}

"Do you know why we took action in this history against FIFA? We're used to it, when there is a fancy party, they always take us out. We will come back anyways. But you know, acarajé is from Iansã, right, so do you think she'd be quiet?”, a baiana told me. This explanation opened my eyes to the ontological claim baianas 
de acarajé were proposing. According to Yoruban knowledge, Iansã positions herself in front of Xangô (an orixá known to be a warrior god) in the battles, helping him and opening the way for this orixá in the wars. In the same sense, the orixá would be guiding the baianas of acarajé to go to fight, impelling them to rebel, to face a stronger power.

Reflecting on this ontology, I came to understand the insistence of baianas to be strongly visible during the FIFA World Cup. Their presence in the streets was the stone in the shoes of the state-business front (Segato, 2014a). When they shared the public space, they were able to reclaim their agency as political actors. Once they were seen in this place, one could not deny their existence; once they were heard, one could not ignore their difference. Therefore, the resignification that black women gave to the public space (equivalent to the political sphere in Modernity) is an essential aspect of the coloniality of gender and power subversion (Segato 2012, Quijano 2014).

This quote also helped me to understand why it was important for the baianas to serve as an example to other groups and collectives who have also been questioning FIFA against the violation of their rights. In an interview, ABAM's President stated that "the most important thing is not to be there to sell but is to be there and to show what we have achieved! Because we opened doors so that other people in other states could now be in the World Cup, the tapioqueiras of Recife and the feijão tropeiro of Minas Gerais". In this sense, their claiming for appearing would be a statement of their and other sellers importance as political, economic and cultural agents.

I understand that in the struggle of the baianas there are still two aspects that are distinctive of their process of resistance: one is that there is a symbolic system that constitutes the Afro-Brazilian identities, built collectively for centuries, and for which they struggle to preserve. And the other is that this process did not begin in the dispute with FIFA, nor does it close with the end of mega-events, but it is also part of the history of black women in Brazil. Therefore, the knowledge inherited when one learns the craft does not only concern the alimentary system in which acarajé is inserted, but also the wisdom related to the conflicts of daily life. 
According Torres, "the insistence on the preservation of an Afro-Brazilian religious symbolic system as a support for its activity during this trajectory resembles what Michel Foucault (1989:89) calls 'diffuse resistance”" (Torres 2007:249). As a result, Torres says that the vendors resisted in their own way, with cultural responses to the immediate adverse situations that were placed in the way. To this repertoire Lélia Gonzalez (1988) denominated amefricanidade.

Amefricanidade, for Gonzalez, reflects the historical experience of the diaspora and the African heritage that revived the forces of resistance and creativity in the struggle against enslavement, extermination, exploitation, oppression and humiliation that the coloniality of power created (1988: 78). In this perspective, Gonzalez explains that in the colonial period, "the revolts, the elaboration of strategies of cultural resistance, and the development of alternative [created] forms of free social organization" (1988: 79) in quilombos, for example, and in the craft of the baianas de acarajé. As I said before, the craft, which is passed from mother to daughter, is an example of amefricanidade. Indeed, it is decolonized difference and strategy of resistance. But baianas de acarajé craft is not only a practical knowledge related to food and the inheritance of resistance; there is also a secret, typical of the trade, shared among the baianas through codes and knowledge that cannot, nor should be, fully translated into the language of the colonizer. From this, I must add to Gonzalez's amefricanidade the knowledge and code proper of the original peoples and diasporic peoples of Brazil.

I understand, therefore, amefricanidade as the strategies of negotiation, adaptation, struggle and survival developed from the experiences, thought and reflexion in a process of intersection between own knowledge and the knowledge of the Other, between their resistant code of the Other.

I think, therefore, that these experiences of struggle, whether through direct confrontation, stubbornness, negotiation, or adaptation, are part of the repertoire of strategies that enslaved Africans during the colony and their descendants activated to carry out their "people's project". That is, to define itself and guarantee the continuity of peoples in history (Segato 2014). 
In conclusion, I consider baianas de acaraje dispute against FIFA is an extended example of amefricanidade. It brings together not only the practical experiences of negotiation and resistance in the daily struggle of colonial relations, but also the mythological knowledge that reflects the expectations, frustrations, desires, needs and propositions of truth that the colonized peoples shared in the continuation of this fight for the project of being as a people.

\section{References}

Araujo, Larissa. S. Baianas de Acarajé contra FIFA: um estudo de caso sobre desenvolvimento e colonialidade. 2015. 240 f.,il Dissertation (Masters in Human Rights and Citizenship) - University of Brasília.

Cardoso, Cláudia Pons. 2012. Outras falas: feminismos na perspectiva de mulheres negras brasileiras. PhD Thesis. Salvador: Salvador: PPGNEIM/UFBA.

Fedération interlationale de Footbal Association (FIFA). Invitation to tender for the rights of the FIFA Food \& Beverage Concessionaire Programme Phase I. Zurich, Switerzland, 30 jan. 2012. Disponível em

<http://www.fifa.com/mm/document/tournament/loc/01/57/49/58/phase1ofitt201 4.pdf>. Acesso em 23 mai. 2015.

González, Lélia. 1988. A categoria político-cultural de amefricanidade. In: Tempo Brasileiro. Rio de Janeiro, No. 92/93 (jan./jun), 69-82.

Machado, Taís de Sant'Anna. 2013. De dendê e baianidade - a construção de um bem cultural denominado comida baiana. In Revista Brasiliense de Pós-Graduação em Ciências Sociais, volume 12, no 1.

National Institute of Artistic and Historical Heritage (IPHAN). 2007. Ofício das Baianas de Acarajé. Brasília, DF: Iphan. 
Quijano, Aníbal. 2014. Cuestiones y horizontes: de la dependencia históricoestructural a la colonialidad/descolonialidad del poder; Clímaco, Danilo Assis (prologue and selection). 1st ed. Ciudad Autónoma de Buenos Aires: CLACSO.

Segato, Rita. 2012. Gênero e colonialidade: em busca de chaves de leitura e de um vocabulário estratégico descolonial. In e-cadernos ces [Online], 18| 2012.

Segato, Rita. 2014. May every people weave the threads of their own history: juridicalpluralism in didactical dialogue with legislators. University of Brasília Law Journal, issue 1, n.1.

Segato, Rita. 2014a. Sex and the norm: state front, patriarchy, dispossession and coloniality. Rev. Estud. Fem. [online]. 2014, vol.22, n.2, pp.593-616.

Torres, Gerlaine Martini. 2007 Baiana do Acarajé: A uniformização do típico em uma tradição culinária afro-brasileira. 2007. 291 f. PhD Thesis (Doctorate in Anthropology) - Department of Anthropology, University of Brasília, Brasília. 